\title{
TRANSLATOR'S RESISTANCE AND ACTIVISM AS A WAY TO CATHARSIS: UKRAINIAN CONTEXT
}

\section{Hrytsiv N. M.}

\section{INTRODUCTION}

The article revolves around the period of totalitarian regime in the $20^{\text {th }}$ century Europe. Evidence and detailed description of the epoch is given by Wielgohs and Pollack ${ }^{1}$. With the goal of acquiring a monopoly on power independent of democratic consent, Soviet occupying forces as well as local Communist parties sought to exclude, co-opt or suppress real or potential political opponents as swiftly as possible on the basis of massive terror, to use Wielgohs and Pollack's concept ${ }^{2}$. Many intellectuals were seen as 'public enemies' or 'especially dangerous state criminals' and were treated accordingly. Taking into account the period of nation's stagnation, I am particularly interested in finding logic and reasons for the fact that agonizing translators found their way to catharsis via creative writing behind the bars.

Intrinsically shaped by the dissident movements, the contemporary Ukrainian literary panorama is represented by a multifaceted image of literature of dissent - original and translated. Some of its representatives were forced to flee the threat of imprisonment or death and sought asylum abroad. The activity of the majority of men of letters who stayed in their country embraces the idea of translation as a necessary creative practice for intellectual development - personal and collective. The strongest desire of the imprisoned literary activists was to contribute to their culture (here Ukrainian) and literary repertoire that would allow it to develop and evolutionize. By this I mean, that they were writing and translating under the constant threat posed to their lives.

In other words, this article focuses primarily on psychological, intimate pains and overwhelming feeling of harshness and injustice of a traumatized translator that is particularly suited to investigating the way in which a translator functioned in situations of a trauma event, moreover, was capable

${ }^{1}$ Wielgohs J., Pollack D. Comparative Perspectives on Dissent and Opposition to Communist Rule. Dissent and Opposition in Communist Eastern Europe. London : Ashgate Pub Ltd, 2004.

${ }^{2}$ Wielgohs J., Pollack D. Comparative Perspectives on Dissent and Opposition to Communist Rule. Dissent and Opposition in Communist Eastern Europe, London: Ashgate Pub Ltd, 2004. P. 22. 
of functioning appropriately in specific situations and socio-cultural contexts. By this I mean that a translator's literary heritage was tremendous and of utmost importance for that time as well as modern Ukrainian literature (original and translated) and culture development.

This article is among the attempts to study the exile translation in conditions of political oppression in a totalitarian context. The aim is to concentrate on homo affectus nature of a translator and perceive his/her creative writing (translations) as a form of artistic expression of his/her dissent and opposition to the milieus.

Amongst the representative figures I have chosen three personalities that were repressed - and so was their creativity - during the totalitarian regime of the $20^{\text {th }}$ century.

Because of his title 'unbreakable poet', I depict Vassyl Stus's (1938 1985) creative power of translating in exile in his attempt to publicly protect democratic freedoms. With regard to his 'unwavering' belief in the power of a translated word, I turn my sights into the personality of Hryhoriy Kochur (1908-1994). With his life credo 'the truth does not need the drums', Vassyl Myssyk (1907-1983) demonstrated vehement, though silent protest. It needs to be stressed that I limit myself to the exilic conditions and creative writing within imprisonment framework of these literary activists. I only partially touch upon the reasons for the arrest of three translators.

Stus, Kochur and Myssyk were intellectuals in Ukraine - their country of origin, who subsequently got arrested and sent to the concentration camps. While in prison, the consciousness of Stus and Kochur was revealed in voicing their range of psychological states - anger, mourning, nostalgia, anxiety - in their creative writings. Being both marginalized and shattered, Myssyk, in contrast, suffered in silence. He, however, understood translation as the only way to enlarge Ukrainian aesthetic sphere and was faithful to this life principle. Posthumously, Stus, Kochur and Myssyk's unbreakable self and contribution to Ukrainian culture was honored by launching the literary prize for original writing and translations, i.e. The Vasyl Stus Prize (since 1989 ) is the first non-governmental prize awarded for 'talent and courage'; The Hryhoriy Kochur Award (launched in 2010); Vassyl Myssyk Literary Prize (established in 1995) is awarded for poetry collections and translations of poetry from foreign languages. Their translationship has been researched by Hrytsiv ${ }^{3}$, Kolomiyets ${ }^{4}$, Rudnytsky ${ }^{5}$. From the viewpoint of their manner of translation, there are certain features the three translators - Stus, Kochur

3 Hrytsiv N. Vassyl Myssyk: the multi-faceted diamond of Ukrainian artistic translation. Vinnytsia : Nova Knyha publishing house, 2017.

${ }^{4}$ Kolomiyets L. Hryhoriy Kochur and the Ukrainian translation. Cherkasy : BramaUkraina, 2008.

${ }^{5}$ Rudnytsky L. Vassyl Stus and German Literature. Relation of the poet to Goethe and Rilke, 1985. URL: http://exlibris.org.ua/stus/r24.html. 
and Myssyk - have in common. Among the priorities in their translators' conception were: translating significant classical works; following the source text concerning the clarity of the motif and innovative poetic forms; distinguishing between elevated and low style, working directly with the source language, without the mediation of other linear translations; refraining from adaptation, distinguishing between translation and transfusion; rendering tropes and figures of the original without an unnecessary overloading with unusual images of the readers' perception; rendering metrical peculiarities and euphony of the source text.

\section{Theoretical and methodological considerations in projection to a traumatized translator}

It may be noted that recent publications show a tendency to address the issue of post colonialism and translation, conflict and translation, translation in exile, or, in short, despoticized agenda of translation and translators ${ }^{6}$. Difficult as it might be to enumerate the range of topics addressed in the studies, there appears to be a tendency to investigate the despoticized nature of translation from two prevailing perspectives: a) socio-cultural and b) person-centered. The translators' creativity is viewed through the prism of sociology of translation, with the intention to reveal geo-political and social contexts of their working conditions and objectively estimate the contribution of translators, their gains and losses in accordance with social and historical contexts.

Situated at the crossroads of sociology, psychology, anthropology and translation studies, the conception of a traumatized translator embraces methodologies from different research fields and, thus, opts for multidisciplinary approach.

In the area of translation (in our case - literary), however, there appears to be very limited methodological basis in researching translator's personal identity following trauma and post-traumatic psychological and social adjustment.

From methodological perspective, the current study heavily concentrates on the sociological factors and various agents involved in the translation process. It presses the requirement to conduct the analysis as based on combining insights from 'sociological turn' and 'activist turn ${ }^{, 7}$, translation

\footnotetext{
${ }^{6}$ Translation Under Fascism. (ed. by Christopher Rundle and Kate Sturge), Palgrave Macmillan. Also: Translation Under Communism, Rundle, Ch. (ed.) (Forthcoming). 2010.

${ }^{7}$ Wolf M. The sociology of translation and its "activist turn". The sociological turn in translation and interpreting studies, ed. Claudia V. Angelelli, Amsterdam : John Benjamins, 2005. P. 7-21. Also: Wolf M. Introduction: The emergence of a sociology of translation. Constructing a sociology of translation, ed. Michaela Wolf, and Alexandra Fukari, Amsterdam : John Benjamins, 2007. P. 1-36.
} 
and activism ${ }^{8}$, and committed approaches and activism in Translation Studies $^{9}$; also trauma and autobiographical memory specificity ${ }^{10}$.

Placing her research within sociological turn in Translation Studies, Wolf notes that it 'marks paradigmatic changes in reflection on the reasons conditioning a translation process ${ }^{11}$, stressing its relation to the problem of translators' status, roles, ethics and responsibilities in society. The development of the sociology of translation in general offers a possibility to investigate the roles and viewpoints of various agents behind the translation process. To mention here Tymoczko ${ }^{12}$ who notes that 'the ideology of a translation resides not simply in the text translated, but in the voicing and stance of the translator, and in its relevance to the receiving audience', pointing to the ideological, geographical and temporal positioning of the translator (the italics are mine).

In this context, the use of methodological platform circumscribed above is proved suitable as it highlights a number of highly relevant aspects which should help elucidate the benefits of creative writing for a traumatized translator and his/her - incorporating Baker's terminology - progressive narrative.

Among others, sociological approach to translation examines macrosocial factors (geographic 'positionality', habitus, etc.) and micro-social factors (how individuals interact to set goals) in literary translation. Despite the methodological benefit the sociological turn has established, it becomes obvious that it is firmly situated in the socio-political circumstances of a given country, showing that translation research is conducted within the

${ }^{8}$ Baker M. (ed.) Translating Dissent: Voices from and with Egyptian Revolution. Abingdon \& New York : Routledge, 2016. Also: Baker M. Blaagaard, Bolette (eds.). Citizen Media and Piblic Space : Diverse Expression of Citizenship and Dissent. Abingdon \& New York : Routledge, 2016. Also: Tymoczko M. (ed.) Translation, Resistance. Activism. Amherst. MA : University of Massachusetts Press, 2010. Also: Tymoczko M. Ideology and the position of the translator: In what sense is a translator 'in between'? In Apropos of Ideology: Translation Studies on Ideology - Ideologies in Translation Studies, Maria Calzada Pérez (ed.). Manchester : St. Jerome, 2003. P. 181-201.

${ }^{9}$ Brownlie S. Committed Approaches and Activism in Translation Studies Research. In: Handbook of Translation Studies. Amsterdam, Philadelphia: John Benjamins Yves Gambier, Luc van Doorslaer, editor(s), 2010. Vol. I. P. 45-48.

${ }^{10}$ Hermans D., Van den Brocek K., Belis G., Raes F., Pieters G., Elen P. (2004). Trauma and autobiographical memory specificity in depressed inpatients. Behavior Research and Therapy. 2004. № 42. P. 775-789.

${ }^{11}$ Wolf M. The sociology of translation and its "activist turn". The sociological turn in translation and interpreting studies, ed. Claudia V. Angelelli, Amsterdam : John Benjamins 2005. P. 8.

${ }^{12}$ Tymoczko M. (2003). Ideology and the position of the translator: In what sense is a translator 'in between'? In Apropos of Ideology: Translation Studies on Ideology Ideologies in Translation Studies, Maria Calzada Pérez (ed.). Manchester : St. Jerome, 2003. P. 181-201. P. 183. 
dichotomy global-local rather than global-local-individual. Therefore, the 'activist turn' marked a milestone in current trends in Translation Studies. To specify, activism is concordant with emphasizing the role of translation and a translator in society. In its broad meaning, activism deals with a deliberate act (personal involvement) for the sake of implementing changes (in our case - in the scope of artistic translation) ${ }^{13}$. Thus, in terms of a translator as an agent of translation, he/she is viewed in triad: homo lingualis - homo socius - homo affectus. This triad fits is studied by Robinson ${ }^{14}$ from the viewpoint of translator's turn with close attention to the moral and intellectual needs of a translator.

\section{Person-centered theory and personality development}

The notion of personal identity in post-traumatic stress period and the following self-concept in culture has attracted much attention in a number of disciplines, and has accordingly been defined in a variety of ways. Much research has been done in the sociological and psychological studies of trauma-related issues (such as trauma events, i.e. accident, natural disaster, non-sexual assault, sexual assault, military combat, war, imprisonment, torture, life-threatening illness, exile etc). To mention here the studies of Jobson and O'Kearney ${ }^{15}$, Berntsen and Rubin ${ }^{16}$, and Bracken ${ }^{17}$. Among the problems discussed in these studies, one of the key concepts remains the connection between trauma memories and posttraumatic stress disorder symptoms, as well as trauma becoming a key to identity.

While the final definition of the notion "traumatized translator" has yet to be agreed upon, the working definition sounds the following way: 'a translator subjected to lasting shock as a result of a disturbing experience or physical injury', which is conceded from the definition of 'trauma' (understood as an emotional response to a terrible event or situation that causes great disruption or suffering) as expounded by American Psychological Association.

Since person-centered, my research is prosopography oriented. I follow the methodological elaborations of Keats-Rohan and analyse the sum of data

${ }^{13}$ Brownlie S. Committed Approaches and Activism in Translation Studies Research. In: Handbook of Translation Studies, Vol. I. Amsterdam, Philadelphia : John Benjamins Yves Gambier, Luc van Doorslaer, editor(s). 2010. P. 45-48.

${ }^{14}$ Robinson D. The Translator's Turn. Baltimore ; London : The John Hopkins University Press, 1991.

${ }^{15}$ Jobson L., O'Kearney R. (2008). Cultural differences in personal identity in posttraumatic stress disorder. British Journal of Clinical Psychology. 2008. № 47. P. 95-109.

${ }^{16}$ Berntsen D., Rubin D.C. (2007). When trauma becomes a key to identity: Enhanced integration of trauma memories predicts posttraumatic stress disorder symptoms. Applied Cognitive Psychology. 2007. № 21. P. 417-431.

17 Bracken P.J. Trauma: Culture, meaning and philosophy. London : Whurr Publishers, 2002. 
about three individuals with the aim to trace the types of connection between them; more importantly, how they operated within and upon the social, political, legal, intellectual institutions of their time ${ }^{18}$.

Embracing many forms of psychological and self- as well as subject-, or reader-centered criticism, subjectivism - a psychological theory in literary criticism - is prioritized in the current research. Psychological criticism holds the assumption that 'literature is the expression of the author's psyche, often his or her unconscious, and, like dreams, needs to be interpreted ${ }^{19}$. On the other hand, sociological criticism 'attempts to relate what happens in texts to social events and patterns, and is as concerned about the effects of texts on human events as about the effects of historical events on texts, ${ }^{20}$. Moreover, sociological criticism assumes that the most significant aspects of human beings are social and that the most important functions of literature thus involve the way that literature both portrays and influences human interactions ${ }^{21}$.

In their collective monograph Creativity in Exile, the authors touch upon the harsh circumstances writers have been compelled by, devastating sense of loss and nostalgia. Scholars do not limit the focus just to writing in exile, but rather to communicate something of the rich diversity of media in which displaced persons express their creativity, as it is stated by Hanne in her Introduction to the collection ${ }^{22}$. I find this idea advantageous if applied to translating in exile or imprisoned. It confirms Torop's observation that 'the creative and mediating processes operating in culture can be treated as a communicative, metacommunicative and autocommunicative complex. Any creator, while creating his/her work, communicates both with the audience and with himself/herself ${ }^{23}$.

Thus, the core characteristics of personality development are (a) self, (b) need for positive regard, and (c) need for positive self-regard. Personality is shaped partly by self-actualization tendencies and partly by others' evaluations ${ }^{24}$.

${ }^{18}$ Keats-Rohan K. History and Computing. 2000. № 12:1. P. 2.

19 The Norton Introduction to Literature. $8^{\text {th }}$ edition. (ed. by Paul Hunter, Alison Booth, Kelly Mays), New York-London, 2002. A4.

${ }^{20}$ Ibid. A23.

${ }^{21}$ Ibid. A23-24.

${ }^{22}$ Hanne M. Creativity and Exile: An Introduction. Creativity in Exile, Editions Rodopi B.V. Amsterdam - New York, 2004. P. 1-13. P. 6.

${ }^{23}$ Torop P. Translation as communication and auto-communication. Sign Systems Studies. 2008. Vol. 36.2. P. 375-397. P. 393.

${ }^{24}$ Sperry R.W. Structure and significance of the consciousness revolution. PersonCentered Review. 1990. № 5 (2). P. 120-129. Also: Rogers C.R. A way of being. Boston. MA : Houghton Mifflin, 1995. 


\section{Translation Studies perspective}

A growing number of recent observations have suggested a significant interest of Translation Studies scholars in researching translator's personality in terms of their visibility in translation ${ }^{25}$, negative and positive analytics ${ }^{26}$, translator's habitus ${ }^{27}$, translator's subjectivity in decision-making and its influence on the development of literary polysystem ${ }^{28}$, limits of translator's choice ${ }^{29}$ and many others. These elaborations add up to what is now addressed as 'personal critique, ${ }^{30}$ as related to a translator's role in the society.

These investigations address a set of related issues of a traumatized translator to a certain extent and, by definition, are inseparable from the notion of 'translator's individuality and/or personality' - free or imprisoned.

The issue under discussed, nevertheless, needs systematization. Therefore, basing on Baker's findings of the framing narratives in translation, I incorporate the following configuration to structure and organize the illustrative subsection.

In her book 'Translation and Conflict: A Narrative account', Baker ${ }^{31}$ has developed a model, which implicitly or explicitly helps to define the motive force for certain meta-communicative phenomena which occur at a certain time under certain circumstances and are constrained by certain conditions.

Analyzed from a viewpoint of semiotics and translation, Torop's ${ }^{32}$ idea of metacommunication and autocommunication echoes with Baker's understanding of meta-narrative and ontological narratives in terms of translator's urgent necessity to voice and advance his/her emotional experience. In addition, Baker ${ }^{33}$ proposes what she defines as 'progressive

${ }^{25}$ Venuti L. The Scandals of Translation: Towards an Ethics of Difference. London and New York : Routledge, 1998.

${ }^{26}$ Berman A. Translation and the Trials of the Foreign. The Translation Studies Reader. L. Venuti (ed.) - New York ; London : Routledge, 2009. P. 276-289.

${ }^{27}$ Gouanvic J.-M. A Bourdieusian theory of translation, or the coincidence of practical instances: field, «habitus», capital and illusion. The Translator. 2014. № 11.2. P. 147-166.

28 Gentzler E. Contemporary Translation Theories. Clevedon : Multilingual Matters, 2001.

${ }^{29}$ Paloposki O. Limits of freedom: Agency, choice and constraints in the work of the translator. Agents of Translation, John Milton and Paul Bandia (eds), Amsterdam Philadelphia : John Benjamins Publishing Company, 2009.

${ }^{30}$ Torop P. Translation as communication and auto-communication. Sign Systems Studies. 2008. Vol. 36.2. P. 375-397.

${ }^{31}$ Baker M. Translation and Conflict: A Narrative account. Abingdon \& New York : Routledge, 2006. P. 145-155.

32 Torop P. Translation as communication and auto-communication. Sign Systems Studies. 2008. Vol. 36.2. P. 375-397.

${ }^{33}$ Baker M. Translation and Conflict: A Narrative account. Abingdon \& New York : Routledge, 2006. 
narrative', which stresses a pattern of change for the better and selfimprovement. In terms of psychology, the notion 'self-actualization' becomes applicable. Thus, self-actualization - according to Ford ${ }^{34}-$ is a person's lifelong process of realizing his or her potential to become a fully functioning person. The goal of self-actualization is to be that "true self" and the direction is toward the "good life", [...] the tendency toward selfactualization became a part of a larger motivational model when the person necessarily becomes optimally growth-oriented ${ }^{35}$.

In terms of Motivational Theory of Life-Spam Development, Heckhausen claims ${ }^{36}$ :

Most people have a sense of being actively involved in shaping their lives. They follow developmental paths that are coherent in terms of identifying and effectively pursuing long-term goals and, when necessary, disengaging from goals that are no longer attainable. Even when confronted with setbacks, disappointments, and failures, humans have a remarkable capacity to stay on course and maintain a sense of personal agency. Our approach to the regulation of life-span development focuses on the impressive adaptive capacity of individuals to optimize development across major changes in the life course. (italics are mine)

In other words, to endeavor - a traumatized person needs to follow this trajectory of positive (self) regard. Here, creative writing served as a constructive way of managing stress and trauma.

Baker's ${ }^{37}$ theoretical and methodological elaborations in the sphere of traumatized personality involved in translation offer a large-scale systematic insight into the problem matter. Despite the fact she prioritizes multimedia translation and text manipulation, highlighted and seen as promising in the current study are Baker's notions of: frame, framing understood as structures of anticipation, strategic moves that are consciously initiated in order to present a narrative in a certain light ${ }^{38}$. Framing is an active process of signification by means of which we consciously participate in the construction of reality; temporal and spatial framing which presupposes selecting a particular text and embedding it in a temporal and spatial context

${ }^{34}$ Cited in: Michael J., Holosko M., Skinner J. (et. al). Person-centered Theory. Comprehensive Handbook of Social work and Social Welfare. 2008. Volume 2 (volume ed. Thyer, B.A.).

${ }^{35}$ Michael J., Holosko M., Skinner J. (et. al). Person-centered Theory. Comprehensive Handbook of Social work and Social Welfare. 2008. Volume 2 (volume ed. Thyer, B.A.).

${ }^{36}$ Heckhausen J., Wrosch C., Schulz R. A Motivational Theory of Life-Span Development. 2010. URL: https://www.ncbi.nlm.nih.gov/pmc/articles/PMC2820305/.

${ }^{37}$ Baker M. Translation and Conflict: A Narrative account. Abingdon \& New York : Routledge, 2006.

${ }^{38}$ Ibid. P. 105-106. 
that accentuates the narrative it depicts and encourages us to establish links between it and current narratives that touch our lives, even though the events of the source narrative may be set within a very different temporal and spatial framework ${ }^{39}$; transcendent issue/values which are the 'ultimate values' people live by and can override any other consideration in assessing a narrative ${ }^{40}$; ontological narratives elucidating personal stories that people tell themselves about their place in the world and their own personal history ${ }^{41}$. They are interpersonal and social in nature but they remain focused on the self and its immediate world; progressive narrative depicting a pattern of change for the better over time and allowing people to see themselves and their surroundings as capable of improvement ${ }^{42}$.

All things considered, I partially incorporate $a$ ) the notions proposed by M. Baker, these are framing, frame ambiguity and frame space within her 'framing narratives in translation' idea; $b$ ) person-centered theory by Roger from the psychology perspective, namely his views on self-actualization, self-regard and stages of the therapeutic process; c) merits of creative writing in exile.

Though nominally, incorporating the above-listed notions (progressive narrative, ontological narratives, frame, temporal and spatial framing, transcendent issue/values) into the current research is promising, first and foremost, from a view point of categorizing, synthesizing and systematizing the illustrative personological data.

\section{Circumscribing temporal and spatial framing of Vasyl Stus, Hryhoriy Kochur and Vasyl Mysyk}

Concentrating on selective aspects of creative writing and a writer himself, important presumption is to unfold the genuine reasons for the development of their creative potential (as was the case with Stus and Myssyk) or the deviation from their regular working trajectory (taking Kochur as an example).

\subsection{Exilic conditions and progressive narrative of Vasyl Stus}

Vassyl Stus (1938-1985) is a human rights activist and a major Ukrainian poet, critic, publicist, and member of the Ukrainian Helsinki Group (UHG); twice a political prisoner who died in the labour camps in Kuchino village of Perm Region.

${ }^{39}$ Ibid. P. $112-113$.

${ }^{40}$ Ibid. P. $171-172$.

${ }^{41}$ Ibid. P. $169-170$.

${ }^{42}$ Baker M. Translation and Conflict: A Narrative account. Abingdon \& New York : Routledge, 2006. P. 170. 
Following the tradition of framing ${ }^{43}$, it might be deduced that Stus managed to abstract away from that time reality, restore his inner reserves in order to unfold his artistic potential, which eventually gave him the strength to withstand the system and vindicate his values.

Ovsiyenko $^{44}$ shares his memoirs that Vassyl Stus arrived in Kuchino in November 1980. Stus was sentenced for 10 years into the special regime camps, with afterwards 5 years of exile. He was labeled an 'honorary' title 'especially dangerous recidivist'. In Kuchino he was monitored with special attention. Most of the things he wrote under strict regime in Mordovia, Stus somehow managed to send to freedom. The pieces were included in his letters. He used to write poetry in continuous line and replaced the sensitive for censorship words (prison - crowd, prickly wire - painful world, Ukraine - motherland). Thus, he has managed to send only 6 poems to his wife. The special regime allowed writing only one letter per month. The letters were constantly rejected or confiscated and labeled by the regime as containing 'prohibited information', 'conventions in the text' or simply 'the letter of suspicious content ${ }^{45}$.

Transcendent values of Stus: Unbreakable poet, with his wife and son in danger, Stus voiced his values in the following lines: "But I was not going to bow down no matter what they had prepared for me. Behind me was Ukraine, my oppressed people, in honor of which I must stand till I die ",46.

In the same camp book Stus ${ }^{47}$ continues:

I have learned In Kyiv that people who are close to Helsinki Group are repressed in the most brutal way. [...] I did not want Kyiv like that. Seeing that the Group remained virtually to the mercy of fate, I joined it, because I could not act otherwise. When the life is taken away - I do not need crumbs... Psychologically I understood that prison gate has already opened for me; that soon it will close behind me - and close for a long time. But what was to be done? The Ukrainians are not allowed abroad. To tell the truth, I was not really eager to go abroad. I want to contribute to Great Ukraine here. I am ready to protest, if it needs protesters. This is fate, and the fate cannot be chosen. Therefore, I accept it no matter what ${ }^{48}$.

Ontological and progressive narratives during the imprisonment period:

${ }^{43}$ Ibid. P. 106.

44 Ovsiyenko V. Death of Vasyl Stus. Human Rights in Ukraine, 2015. URL: http://khpg.org/en/index.php?id=1441192456.

${ }^{45}$ Ibid.

${ }^{46}$ Stus V. (1994). From the camp notebook. Tvory $v$ shesty tomakh (Writings in six volumes). Lviv : Prosvita, 1994. Volume 4. P. 491.

${ }^{47}$ Ibid. P. 493.

${ }^{48}$ Cited in: Ovsiyenko V. Death of Vasyl Stus. Human Rights in Ukraine. 2015. URL: http://khpg.org/en/index.php?id=1441192456. 
The whole context of The camp notebook exposes painful contemplations about the reasons for our national tragedy, about our history and culture - past and present. According to Ovsiyenko ${ }^{49}$, existential issues are identified as key in Stus's camp notes. The author was able to declare his own beliefs and views of life which he was fortunate to share with a wide reader community. The consequences of this act of the poet turned fatal for him. The 16 shreds occupied only 12 pages in the book, nevertheless, their explosive force resulted in exterminating all the other writings of Stus. From the words of Ovsiyenko it can be concluded that one of the causes of Stus's homicide was the publication of these texts in the West, i.e. outside Soviet republic (in Amsterdam).

From his five years in Kuchino there were left 45 letters, 6 poems and the text, which is called in the publications From the camp notebook.

Those were regular searches Stus hated most of all. Apart from humiliation, he suffered severely when his poetry was found and destroyed. During one of the searches three hundred of his creative pieces were confiscated.

During one of the talks with a jail keeper Stus was lamenting:

So you are saying that you put my manuscripts in the warehouse behind the zone. Of course I know that you want nothing to be left from me after I die... I don't write anything of my own now, only translating. So give me a chance to finish something, at least... ${ }^{50}$.

The possibility to translate was partially preconditioned by camp regulations. Prisoners were allowed to have five books, magazines and brochures in cell in total. They could have a textbook and a dictionary to learn foreign languages. By the time of imprisonment Stus had mastered German and English, so he was learning French. The little pieces of paper with the foreign words to learn the language were confiscated by guards as their possession was regarded as a violation of camp regime.

It was Stus's passion and burning desire to write that caused him so much trouble. If keeping himself from writing in captivity, Stus would have avoided numerous times in solitary confinement.

In February 1983 Stus was thrown in a solitary confinement for a year ${ }^{51}$. Ovsiyenko recollects his memories from that time:

When he left it, I met him in cell 18 for some six weeks. I have read his improvised rough notebook with blue cover (without a title) with several dozens of poems written in free verse, and the notebook with the translations of 11 elegies of Rilke. I was then in grave physical condition (my heart hurt)

${ }^{49}$ Ibid.

51 Ovsiyenko V. Death of Vasyl Stus. Human Rights in Ukraine. 2015. URL: http://khpg.org/en/index.php?id=1441192456. 
and was not able to learn any single poem. And I didn't expect that we would be parted so soon.

In 1983 in his letters Stus described the collection of poetry which he entitled "Bird of the Soul". It contained approximately forty poems ${ }^{52}$. In the year 1985 he already mentioned the completion of poems summing up to one hundred. $\mathrm{He}$ also referred to the translations of highly complex and sophisticated pieces from Rilke, in particular "Elegies" 53 . In terms of ontological narratives, the "Elegies" of Rilke are the quintessence of existential anxiety. In his selective appropriation, Stus privileged the experience of Rilke and framed into his own biographical narrative via translation.

In his memoirs Vasyl Ovsiyenko - a co-prisoner of Vasyl Stus - apart horrific details of torture and poor living conditions, confesses that the most difficult thing was to withstand the psychological pressure.

Stus's writing genius and humanistic position was heavily supported, among others, by a Nobel-prize winner Heinrich Theodor Böll, who repeatedly addressed Soviet representatives in appeal to set Stus free. An iconic figure of the human rights movement in Soviet Ukraine and one of the leading dissident Ukrainian poets of his generation, Vasyl Stus remained faithful to his values.

\subsection{Exilic conditions and progressive narrative of Hryhoriy Kochur}

Hryhoriy Kochur (1908-1994) was sentenced to penal servitude in GULAG mines in 1943 and released in 1953. He was sent to Soviet labor camps but turned his experience there into a period of creative activity.

Drozdovsky $^{54}$ sums up that after the Nazi occupation, the Soviet authorities accused Kochur of 'Ukrainian bourgeois nationalism' and sentenced him to 10 years (1943-1953) in the Inta camp with a ban on travel outside the Komi Autonomous Soviet Socialist Republic. While in the camp, Kochur translated, wrote poems and learned foreign languages. Fellow inmates gave Kochur the books they received from their relatives. In such a way, Kochur once received a volume of Edgar Allan Poe's poetry and translated "The Raven" from that collection into Ukrainian. His notebook was as small as a matchbox which he was able to use in his free time.

Transcendent issue/values: unwavering translator, Kochur believed that literary translation has the potential to trigger culture development in

${ }^{52}$ Stus V. (1994). From the camp notebook. Tvory $v$ shesty tomakh (Writings in six volumes). 1994. Lviv: Prosvita, 1994. Volume 4. P. 444-449.

${ }^{53}$ Ibid. P. 444.

${ }^{54}$ Drozdovsky D. Hryhoriy Kochyr: Unwavering Translator. The Ukrainian Week. 2012. URL: http://ukrainianweek.com/History/39394. 
situations when original literature was under peer censorship. Kochur translated from almost thirty national literatures.

He turned his camp experience into a period of creative activity. His fellow inmates were representatives of different cultures and native speakers of different languages, which facilitated the intercultural communication. Kochur managed to indulge in poetry rather than absorb cruel reality. Dreaming of freedom and new generation of intellectuals, Kochur wrote such lines:

I have to become the voice of those,

Whose breath got cold...

... I have to become the voice of those

Who in myriads for so many years

Amongst tundra with questions acutely painful

Prostrating, are stumping ${ }^{55}$.

Ontological and progressive narratives during the imprisonment period

Underground poetry of Kochur is represented in his Inta notebook (Inta diary). Interestingly, this became his temporal and the only one practice of original poetry writing. Inta Notebook contains only twenty seven poems, but each one of them is a unique continuum, worth a separate study. Some poems have author's dating, while others do not possess a date inprint obviously somewhat was restored from memory or revisited. However, the poems are not presented in a chronological order. The superficial look at the lines will show nothing but disillusion, hence hinting the reader to look deep and to re-conceptualize the psychological conflict in the mind of the lyric hero, nuances of his attitude to the world and environment, to the comrades in misfortune $e^{56}$.

Meditative lyric that demands thoughtful attention and empathy, most texts have initiations or appeals - to the wife, friends, to the past, classical poets, and to himself and his "twin".

\subsection{Exilic conditions and progressive narrative of Vasyl Mysyk}

Vasyl Myssyk (1907-1983) is chosen as a study model due to the fact that his life and work circumstances are a rich basis for researching translator's resistance and activism. A translator of world's paramount creative writings, Vassyl Myssyk (1907-1983) stands out against a background of the creativity of other activist translators in Ukraine - mainly due to his biography. His early translation career started in 1932 and lasted by the year 1934. In 1932 the first collection of translated verses entitled Robert Burns "Songs and Poems" was published. In 1934 an excerpt of the novel by John Roderigo Dos Passos

${ }^{55}$ Kochur, H. Intynsky zoshyt (Inta notebook). Kyiv : Molod, 1989. P. 12.

${ }^{56}$ Koloshuk N. Poetyka virshuvannya v "Intynskomu zoshyti" Hryhoriia Kochura ta poetiv "Intynskoi shkoly”. Literaturoznavchi studiyi. 2015. Issue 45. P. 115-124. 
"1919" was published with the indication to be continued. The same year Myssyk was arrested and spent five years of exile in Solovky concentration camp. In 1949 he was set free and in the year 1958 he was rehabilitated. His translations were monitored and shadowed ever since. Admittedly, his creativity - original writings and translation-related activity - was under peer supervision and censorship of power institutions.

Taking into consideration these facts, it should be cleared that Myssyk never rose in rebellion against such injustice. Instead, he found his way to catharsis via poetry writing and translating.

Despite everything, Myssyk's success in his after exile translations include: the collections of translations enlist R. Burns' poetry (1959); O'Henry novel "Cabbages and Kings" (1962, republished in 1980); W. Shakespeare's drama "Timon of Athens" (1964); J. Keats' poems (1968), and others ${ }^{57}$. All of these professional translations changed the image of modern Ukrainian translation.

What was he doing to overcome the most traumatized period of his life? What gave him the strength and the impetus to continue translating?

The preliminary observations show that there were certain aspects which kept him afloat, i.e. solidarity networking, positive projection from the past and the so-called Freud's 'talking cure' (writing/translating cure).

'Talking' your fears was a rare practice in totalitarian Ukraine, therefore it was modulated as a 'writing and translating for the cure' in Myssyk's case. His first writings of that period were done secretly, and were never meant for the public eyes. To mention here his translations of Thomas Hood's "Faithless Sally Brown" (translated in 1939), Henry Longfellow's "A Dutch Picture" (translated in 1940), Robert Stevenson's "Christmas at Sea" (translated in 1940); the handwritten copies are now kept in his archive in his native town of Kharkiv.

This time spam is of particular interest to us. These are the only known translations Mysyk did into Russian. My suggestion is that he did it with the intention not to jeopardize the lives and reputation of his sibling sister and her relatives who hosted him during his after-imprisonment period as there seems to be no other logic. The matter is he never wrote in or translated into Russian. After literary rehabilitation in 1956, as a gesture of his silent protest he refused to translate from Russian or other CIS countries.

In addition, he translated into Ukrainian exclusively while doing his time in labor camp.

For some writers and creative artists, forced to quit their literary activity for a certain period of time, the first priority was to maintain their original skills of poeticizing. Eventually, positive projection from Myssyk's past gave his a

57 Mysyk V. Zustrichi (The meetings). Kharkiv : Prapor, 1982. Also: Mysyk V. Zhyttia vymahaye novatorstva (Life calls for novelty): from the poet's notes. Literary Ukraine. 1987. Issue from July 23. 
glimpse of hope regardless of the impasse situation he was facing. In terms of translations, he was reconsidering, editing, re-translating, and improving the already published translations of his. This later resulted in multiple versions of his translations of R. Burns's poetry, which he translated into Ukrainian.

Solidarity networking (in M. Baker's terminology) was most felt when Myssyk's comrade poets and translators were helping him, despite jeopardizing their own reputation and life. To mention here a literary activist Rylsky who was supporting Myssyk financially and was promoting Myssyk's new collection of Burns's translations; the collection was eventually published and had a tremendous influence on the development of Ukrainian culture ${ }^{58}$.

Shortly after World War II broke out, Myssyk joined the army and, while a war prisoner in Germany during the year 1945, had a chance to flee to the United States. He escaped from captivity, however chose to come back to Ukraine instead. The question of returning not just home, but returning to literature, which was his first priority, allowed Myssyk to maintain his identity and selfregard as fully as possible. During his stay in Germany he took notice of German folklore songs which he later published in Ukraine.

Myssyk (1982; 1987) stated - rephrasing his words - that a creative artist needs constantly work on his/her self-development and master creative skills in order not to think about it in the very process of creating. This persuasion of his marked his way to success and catharsis.

\section{CONCLUSIONS}

The phenomenon of a traumatized translator personality is advantageous when studied in unity of personological, historical, sociological approaches. Such a combination enables conducting the full-fledged analysis within the framework global-local-individual as well as homo-lingualis - homo sociushomo affectus.

By summarizing exilic conditions of three personalities - Stus, Kochur, Myssyk - the following conclusion is drawn: creative writing became a key to moral survival and resistance for the translators, each finding their own way. Oppressed and marginalized, translators often felt inner conflicts and fear for life, but under no circumstances did they diminish their self-efficacy. This phenomenal feature of Ukrainian translators (of a discussed period) became the integral part of their grit, their worldview and lifestyle. Their self-efficacy became verbalized in their progressive narrative which was represented in their creative writing and materialized in their poetry and translations in order to embed intellectual and moral environment.

58 Strikha M. Vasyl Mysyk - the one who survived in Solovky. Ukraina Moloda. 2012. URL: http://www.umoloda.kiev.ua/number/2065/163/73564/. 
Further and detailed analyses conducted, the discussed issue poses the potential to establish a certain framework of behavior of the translators in need at present.

\section{SUMMARY}

The last decade has seen the increased interest among Translation Studies scholars in the aspect of personal critique as related to a translator's role in a society. In this respect, the topical issue - though rarely discussed - is the approach on how to study therapeutic and, at times, cathartic purpose for translating and creative writing. Therefore, among the main questions asked in this study is: how does a translator succeed after a traumatized experience as well as how to research this phenomenon? In addition, the stimulus for researching the topic on translator's resistance and activism comes from the intention to address a key historical theme from the point of view of translation, providing a case study on translation in totalitarian context; more importantly, to decipher what motivates or inspires a traumatized translator to bring translated texts to a reader and how does it help him/her to obtain positive self-regard. The preliminary observations show that there were certain aspects which kept underground dissident translators afloat, i.e. positive projection from the past and the so-called Freud's 'talking cure' (writing/translating cure), solidarity networking. Since 'talking' your fears was a rare practice in totalitarian Ukraine, in the majority of cases it was modulated as a 'writing and translating for the cure', which is investigated in this paper from the viewpoint of 'creative writing in exile'. Based on the study results, I hypothesize it was due to translators' strong and uncompromising belief in their self-efficiency which necessitated them to write and translate for the sake of culture survival, in such a way paving themselves the way to catharsis.

\section{REFERENCES}

1. Baker M. Translation and Conflict: A Narrative account. Abingdon \& New York : Routledge, 2006.

2. Baker M. (ed.) Translating Dissent: Voices from and with Egyptian Revolution. Abingdon \& New York : Routledge, 2016.

3. Baker M. Blaagaard, Bolette (eds.). Citizen Media and Piblic Space : Diverse Expression of Citizenship and Dissent. Abingdon \& New York : Routledge, 2016.

4. Berman A. Translation and the Trials of the Foreign. The Translation Studies Reader. L. Venuti (ed.) New York ; London : Routledge, 2009. P. 276-289.

5. Berntsen D., Rubin D.C. When trauma becomes a key to identity: Enhanced integration of trauma memories predicts posttraumatic stress disorder symptoms. Applied Cognitive Psychology. 207. № 21. P. 417-431. 
6. Bourdieu P. In Other Words, trans. Matthew Adamson, Stanford : Stanford University Press, 1990.

7. Bracken P.J. Trauma: Culture, meaning and philosophy. London : Whurr Publishers, 2002.

8. Brownlie S. Committed Approaches and Activism in Translation Studies Research. In: Handbook of Translation Studies. 2010. Vol. I. Amsterdam, Philadelphia : John Benjamins Yves Gambier, Luc van Doorslaer, editor(s). P. 45-48.

9. Chesterman A. From 'Is' to 'Ought': Laws, Norms and Strategies in Translation Studies. Target. 1993. Vol. 5 (Iss. 1). P. 1-20.

10. Creativity in Exile. Hanne, M. (ed.), Amsterdam - New York, 2004.

11. Drozdovsky D. (2012). Hryhoriy Kochyr: Unwavering Translator. The Ukrainian Week. 2020. URL: http://ukrainianweek.com/History/39394.

12. Gentzler E. Contemporary Translation Theories. Clevedon : Multilingual Matters, 2001.

13. Gouanvic J.-M. A Bourdieusian theory of translation, or the coincidence of practical instances: field, «habitus», capital and illusion. The Translator. 2014. № 11.2. P. 147-166.

14. Hanne M. (2004). Creativity and Exile: An Introduction. Creativity in Exile, Editions Rodopi B.V., Amsterdam - New York, 2004. P. 1-13.

15. Heckhausen J., Wrosch C., Schulz R. A Motivational Theory of LifeSpan Development. 2010. URL: https://www.ncbi.nlm.nih.gov/pmc/articles/ PMC2820305/

16. Hermans D., Van den Brocek K., Belis G., Raes F., Pieters G., Elen P. Trauma and autobiographical memory specificity in depressed inpatients. Behavior Research and Therapy. 2004. № 42. P. 775-789.

17. Jobson L., O'Kearney R. (2008). Cultural differences in personal identity in post-traumatic stress disorder. British Journal of Clinical Psychology. 2008. № 47. P. 95-109.

18. Keats-Rohan K. History and Computing. 2000. № 12:1.

19. Kolomiyets L. Translation as an Asymmetric Response to Soviet Colonialism in the Works of Ukrainian Dissident Poet-Translator Hryhoriy Kochur. Protest and Dissent. Conflicting Spaces in Translation and Culture. Pantuchowicz, Agnieszka and Anna Warso (eds.) Peter Lang GmbH, 2020. P. 89-103.

20. Michael J., Holosko M., Skinner J. (et. al). Person-centered Theory. Comprehensive Handbook of Social work and Social Welfare. 2008. Volume 2 (volume ed. Thyer B.A.).

21. Ovsiyenko V. Death of Vasyl Stus. Human Rights in Ukraine. 2015. URL: http://khpg.org/en/index.php?id=1441192456.

22. Paloposki O. Limits of freedom: Agency, choice and constraints in the work of the translator. Agents of Translation, John Milton and Paul 
Bandia (eds), Amsterdam - Philadelphia : John Benjamins Publishing Company, 2009.

23. Popa I. (2006). Translation channels: A primer on politicized literary transfer. Target. 2006. № 18 (2). P. 205-228.

24. Robinson D. The Translator's Turn. Baltimore ; London : The John Hopkins University Press, 1991.

25. Rogers C.R. A way of being. Boston. MA : Houghton Mifflin, 1995.

26. Sperry R.W. Structure and significance of the consciousness revolution. Person-Centered Review. 1990. № 5 (2). P. 120-129.

27. The Norton Introduction to Literature. $8^{\text {th }}$ edition. (ed. by Paul Hunter, Alison Booth, Kelly Mays), New York-London, 2002.

28. Torop P. Translation as communication and auto-communication. Sign Systems Studies. 2008. Vol. 36.2. P. 375-397.

29. Translation Under Communism, Rundle, Ch. (ed.) (Forthcoming).

30. Translation Under Fascism. (ed. by Christopher Rundle and Kate Sturge), Palgrave Macmillan, 2010.

31. Trauma and shock. American Psychological Association. URL: http://www.apa.org/topics/trauma/.

32. Tymoczko M. (ed.) Translation, Resistance. Activism. Amherst. MA : University of Massachusetts Press, 2010.

33. Tymoczko M. Ideology and the position of the translator: In what sense is a translator 'in between'? In Apropos of Ideology: Translation Studies on Ideology - Ideologies in Translation Studies, Maria Calzada Pérez (ed.), 181-201. Manchester : St. Jerome, 2003.

34. Venuti L. (1998) The Scandals of Translation: Towards an Ethics of Difference, London and New York : Routledge, 1998.

35. Wielgohs J., Pollack D. Comparative Perspectives on Dissent and Opposition to Communist Rule. Dissent and Opposition in Communist Eastern Europe. London : Ashgate Pub Ltd, 2004.

36. Wolf M. The sociology of translation and its "activist turn". The sociological turn in translation and interpreting studies, ed. Claudia V. Angelelli, Amsterdam : John Benjamins, 2005. P. 7-21.

37. Wolf M. Introduction: The emergence of a sociology of translation. Constructing a sociology of translation, ed. Michaela Wolf, and Alexandra Fukari, Amsterdam : John Benjamins, 2007. P. 1-36.

38. Гриців Н. Василь Мисик: різногранний діамант українського художнього перекладу. Вінниця : Нова Книга, 2017.

39. Колошук Н. (2015). Поетика віршування в «Інтинському зошиті» Григорія Кочура та поетів «Інтинської школи». Літературознавчі студіï. 2015. Вип. 45. С. 115-124.

40. Кочур Г. Інтинський зошит. Київ : Молодь, 1989. 
41. Мисик В. Життя вимагає новаторства. Літературна Україна. 1987. 23 липня.

42. Мисик В. Зустрічі. Харків : Прапор, 1982.

43. URL: http://www.umoloda.kiev.ua/number/2065/163/73564/.

44. Рудницький Л. Василь Стус і німецька література. Відношення поета до Гете і Рільке. 1985. URL: http://exlibris.org.ua/stus/r24.html.

45. Стріха М. Василь Мисик - той, хто вижив на Соловках. Україна молода. 2012.

46. Стус В. Таборові записки. Твори : у 6 т. Львів : Просвіта, 1994. Том 4.

\section{Information about the author:} Hrytsiv N. M.

Candidate of Philological Sciences, Associate Professor, Associate Professor at the Department of Applied Linguistics

Lviv Polytechnic National University 12, Stepana Bandery str., Lviv, 79000, Ukraine 